\title{
Studi Empiris Persepsi Kantor Akuntan Publik Terhadap Peranan Karakteristik soft Skill Lulusan Akuntansi
}

\author{
Anna Sofia Atichasari \\ asatichasari@unis.ac.id \\ Akuntansi Universitas Islam Syekh Yusuf Tangerang
}

\begin{abstract}
Penelitian ini bertujuan memberikan bukti empiris mengenai karakteristik soft skill yang dibutuhkan KAP dalam merekrut lulusan akuntansiserta kategori soft skill yang paling diinginkan KAP selain pengetahuan akuntansi. Metode yang digunakan bersifat deskriptif. Teknik penelitian yang dilakukan menggunakan questioner sebagai alat dalam mengumpulkan data. Modus komunikasi yang akan digunakan dengan memanfaatkan e-mail survey, skala pengukuran yang digunakan adalah skala interval dan metode pengukuran kepentingan menggunakan skala Likert. Populasi dalam penelitian ini yaitupraktisi yang memiliki kewenangan dalam menerima lulusan akuntansi (akuntan pemula) dalam hal ini managing partner, manajer, supervisor dan senior auditor dari Kantor Akuntan Publik (KAP) dan terpilih sampel sebanyak 71 yang layak untuk di uji. Dari 54 indikator yang di uji, hanya 39 karakteristik yang bisa dilanjut untuk dikategorikan menjadi 9 kategori terpilih yaitu perilaku profesional, accounting knowledge, kepribadian interpersonal, ketrampilan interpersonal, gender, etika, lulusan perguruan tinggi terkemuka, keterlibatan dalam komunitas profesi serta pengalaman kerja.
\end{abstract}

Kata Kunci : Karakteristik soft Skill Lulusan Akuntansi

\section{LATAR BELAKANG}

Persaingan yang kompetitif mengakibatkan banyaknya dunia kerja khususnya bidang akuntansi disebabkan tidak seimbangnya penawaran kerja para lulusan akuntansi dengan permintaan perusahaan membuat para perekrut selektif dalam merekrut akuntan pemula yang sesuai dengan kualifikasi perusahaan. Karena perusahaan dalam menjalankan bisnisnya membutuhkan karyawan yang mempunyai skill dan bakat yang penting bagi perusahaan yang berorientasi bisnis. Tidak hanya kemampuan teknis dalam akuntansi dan keuangan namun juga dibutuhkan kemampuan lain seperti Interpersonal skill, mampu bekerjasama dengan klien, termasuk kemampuan berkomunikasi, mampu bekerja baik secara individu maupun team, serta memahami perbedaan budaya dalam era globalisasi. Dan yang paling penting adalah kemampuan beradaptasi terhadap perkembangan pengetahuan dan memahami bagaimana mengembangkan kualifikasi profesional mereka. Saat ini banyak perguruan tinggi sudah menghasilkan alumni-alumni program studi akuntansi, namun tidak diiringi dengan kualitas para alumni tersebut sehingga dunia bisnis pun semakin selektif dalam merekrut karyawan akuntansi yang sesuai dengan harapan dan kualifikasi mereka. Persaingan kerja yang terjadi saat ini membuat para dunia bisnis semakin selektif dalam menerima karyawan akuntansi. Indonesia pernah melakukan jejak pendapat kepada 135 responden di Jabodetabek yang dilakukan oleh Pusat Analisa Data Tempo (2007) mengenai kualitas lulusan perguruan tinggi dari sudut pandang dunia kerja. Respondennya adalah para manajer personalia dan penyedia tenaga kerja di Jabodetabek, wilayah tersebut sengaja dipilih karena memiliki konsentrasi lapangan kerja tertinggi di Indonesia. Salah satu hasil dari riset tersebut adalah karakter penting yang diinginkan dalam dunia kerja yaitu mau bekerja keras, kepercayaan diri tinggi, mempunyai visi ke depan, bisa bekerja dalam tim, memiliki perencanaan yang matang, mampu berpikir analitis, mudah beradaptasi, mampu bekerja dalam tekanan, cakap berbahasa Inggris serta mampu mengorganisasi pekerjaan. Serta peringkat karaktersitik yang 
diinginkan dalam dunia kerja adalah indeks prestasi kumulatif menduduki peringkat pertama, kemampuan bahasa Inggris, kesesuaian program studi dengan posisi kerja, nama besar perguruan tinggi, pengalaman kerja/magang, kemampuan aplikasi komputer, pengalaman berorganisasi serta yang menduduki peringkat terakhir yaitu rekomendasi. Dan untuk menjadi akuntan profesional, akuntan pemula diharapkan memiliki tiga bidang pengetahuan utama yaitu (1) akuntansi, keuangan dan pengetahuan yang berkaitan akuntansi, (2) pengetahuan organisasi dan bisnis, (3) pengetahuan teknologi informasi dan kompetensi. Dan juga tidak kalah pentingnya sebaiknya juga memiliki keahlian intelectual skill, technical and functional skill, personal skill, interpersonal and communication skill, organizational and business management skillseperti yang disyaratkan oleh International Education Standard. Oleh karena itu penelitian ini dilakukan untuk mengetahui karakteristik akuntan pemula yang diinginkan para perekrut.

\section{LANDASAN TEORI}

\section{Karakteristik Lulusan akuntansi yang diinginkan Kantor Akuntan Publik}

Ahadiat and Smith (1994) dalam penelitiannya melakukan pengujian karakteristik akuntan pemula yang diinginkan perekrut sebagai responden pada kantor akuntan publik, bank, rumah sakit, industri manufaktur serta institusi pemerintah. Studi tersebut difokuskan pada kriteria karyawan yang dipilih responden dengan memberikan metode dan prosedur dalam mengukur tingkat kepentingan sifat para calon akuntan pemula. Pertanyaan quesioner berkaitan dengan 95 karakteristik sifat karyawan seperti penampilan, pendidikan, etika, kegiatan ekstrakurikuler, kinerja dan kepribadian. Dari hasil analisa faktor eksplorasi dan konfirmasi para responden memberikan 68 dari 95 karakteristik sifat karyawan akuntansi yang loading menjadi 22 faktor sifat, yaitu dari urutan tertinggi hingga terendah dari berbagai sifat yang diiginkan perekrut yaitu perilaku profesional, dapat diandalkan, memiliki standar etika, kemampuan komunikasi, mampu mengatasi permasalahan pribadi, dewasa, penampilan, watak pribadi, kecocokan/keserasian, potensi untuk maju, mampu beradaptasi, kemauan untuk lembur, lulusan akuntansi, pengalaman kerja, lulusan universitas terakreditasi, referensi, prestasi akademik, keterlibatan dalam komunitas profesional, fleksibilitas dalam perjalanan dinas, lulusan sarjana dan sertifikasi profesional, ektrakulikuler serta nilai ujian masuk. Dan hasil studi tersebut konsisten dengan penelitian sebelumnya yaitu pencapaian prestasi, kepribadian dan faktor sosial merupakan karakteristik yang diinginkan oleh responden. Bahkan dalam studi tersebut memberikan faktor paling signifikan yang diinginkan responden yaitu perilaku profesional dimana hal ini kontras dengan penelitian sebelumnya bahwa yang faktor yang paling penting adalah rata-rata IPK. Seperti yang diungkapkan oleh Reigle dan Accounting Education Change Commission dalam Ahadiat and Smith (1994) bahwa kemampuan akuntansi secara teknis belum cukup untuk sukses dalam profesi akuntan di era 90-an, bahkan perusahaan merekrut akuntan pemula yang memiliki beraneka ragam sifat disamping karir akademisinya. Ahadiat and Smith(1994) juga melakukan perbandingan terhadap perekrut dari enam kelompok populasi yang terdiri dari KAP lokal dan internasional, perbankan, rumah sakit, industri manufaktur serta kantor pemerintah. Pada KAP besar menekankan pada potensi untuk maju dan prestasi akademik. Fleksibilitas dalam perjalanan dinas, lulusan sarjana dan sertifikasi profesional serta nilai ujian masuk menunjukkan kurang signifikan pada KAP lokal dibandingkan perekrut dari non KAP. Perekrut dari perbankan lebih menekankan pada kemampuan mengatasi permasalahan pribadi, penampilan serta kecocokan/keserasian. Sedangkan perekrut dari rumah sakit lebih menekankan pada watak pribadi, pengalaman kerja, dan referensi,disamping itu lulusan sarjana dan sertifikasi profesional lebih penting dibandingkan perekrut dari KAP. Sedangkan perekrut dari industri manufaktur menekankan pada lulusan dari universitas terakreditasi serta fleksibel dalam perjalanan dinas. Dan yang terakhir, perekrut dari instansi pemerintah, kurang menekankan 
pada kemauan lembur waktu dikarenakan jadwal pekerjaan relatif stabil dibandingkan lainnya. Rekomendasi yang diberikan Ahadiat and Smith (1994) dalam mengembangkan berbagai karakter sifat yang diinginkan oleh perekrut yaitu para pendidik diharapkan mengevaluasi kembali metode pengajarannya untuk mengembangkan kemampuan berpikir secara kritis, kemampuan komunikasi secara lisan maupun tertulis, menyesuaikan dengan perilaku profesional dan perilaku beretika, karena karakter tersebut merupakan karakter yang paling diinginkan oleh perekrut.

Penelitian serupa juga dilakukan Moncada and Sanders (1999) mengenai karakteristik akuntan pemula yang digunakan dalam memilih kandidat akuntan pemula dalam interview awal dan interview selanjutnya. Penelitian ini menguji persepsi pada tiga kelompok responden, yang terdiri dari KAP, fakultas dan mahasiswa. Hasil penelitian tersebut pada persepsi KAP yang sudah diperingkat adalah nilai IPK akuntansi, mandiri, jiwa kepemimpinan, nilai IPK, kepandaian dalam menulis, potensi untuk maju, kepandaian teknis, reputasi universitas, kegiatan ekstrakulikuler, pengalaman kerja, penampilan yang menarik, keterlibatannya dalam komunitas, profesi, dan organisasi mahasiswa, lulusan dari universitas terakreditasi, referensi, fleksibel dalam perjalanan dinas, serta lulusan sarjana. Sedangkan kategori yang dipilih dalam interview kedua adalah kemampuan interpersonal, kecocokan dengan perusahaan, kemampuan komunikasi secara lisan, memiliki semangat yang tinggi, kedewasaan, standar etika, mandiri, pengalaman kepemimpinan, potensi kenaikan jabatan, kecocokan/keserasian, kepandaian menulis, penampilan yang menarik, kemampuan berorganisasi, nilai IPK akuntansi, kepandaian teknis, nilai IPK, kemauan lembur waktu, kegiatan ekstrakulikuler, pengalaman kerja, keterlibatan dalam organisasi, keterlibatan dalam profesi, referensi, fleksibilitas perjalanan dinas, keterlibatan dalam organisasi mahasiswa, serta lulusan sarjana. Persepsi fakultas mengenai karakteristik yang digunakan dalam pemilihan para kandidat akuntan pemula pada interview awal adalah nilai IPK akuntansi,nilai IPK,reputasi universitas,jiwa kepemimpinan,mandiri,potensi untuk maju, keterlibatan dalam organisasi mahasiswa,kepandaian teknis,kegiatan ekstrakulikuler,kemampuan dalam menulis,penampilan yang menarik,keterlibatan dalam profesi,lulusan dari universitas terakreditasi,pengalaman kerja,keterlibatan dalam komunitas dan organisasi mahasiswa, fleksibel dalam perjalanan dinas,referensi,serta lulusan sarjana. Dan untuk interview kedua adalah kemampuan interpersonal, kemampuan komunikasi secara lisan, kecocokan dengan perusahaan,kedewasaan, potensi untuk maju,memiliki semangat yang tinggi, penampilan yang menarik, pengalaman kepemimpinan, kecocokan/keserasian, mandiri, nilai IPK akuntansi,kemampuan menulis,nilai IPK, kemampuan berorganisasi, kepandaian teknis, standar etika, kegiatan ekstrakulikuler,kemauan lembur waktu, pengalaman kerja,fleksibel dalam perjalanan dinas, keterlibatan dalam organisasi mahasiswa, keterlibatan dalam profesi,referensi,serta lulusan sarjana. Persepsi mahasiswa mengenai karakteristik yang digunakan dalam pemilihan para kandidat akuntan pemula pada interview awal adalah nilai IPK akuntansi,jiwa kepemimpinan,nilai IPK,pengalaman kerja,mandiri,potensi untuk maju,penampilan yang menarik, keterlibatan dalam profesi, kemampuan menulis, kepandaian teknis, reputasi universitas, kegiatan ekstrakulikuler, keterlibatan dalam organisasi mahasiswa, lulusan dari universitas terakreditasi, referensi, keterlibatan dalam komunitas, fleksibel dalam perjalanan dinas,serta lulusan sarjana. Dan untuk interview kedua adalah kemampuan komunikasi secara lisan, kecocokan dengan perusahaan, kemampuan interpersonal, kedewasaan, memiliki semangat yang tinggi, pengalaman kepemimpinan, kemampuan berorganisasi, penampilan yang menarik, kecocokan/keserasian, potensi untuk maju, mandiri, standar etika, pengalaman kerja, kemampuan menulis, nilai IPK akuntansi, kepandaian teknis, keterlibatan dalam profesi, nilai IPK, kemauan lembur waktu, fleksibel dalam perjalanan dinas, kegiatan ekstrakulikuler, referensi, keterlibatan dalam komunitas dan organisasi mahasiswa, serta lulusan sarjana. Dari hasil studi tersebut terdapat perbedaan- 
perbedaan persepsi yang signifikan pada tiga kelompok responden tersebut, yaitu pada interview awal meliputi kemandirian, kemampuan menulis, reputasi universitas dan pengalaman kerja. Sedangkan perbedaan persepsi pada interview kedua meliputi standar etika, potensi untuk maju. Dan kriteria terbaik yang dinilai perekrut dalam memilih akuntan pemula pada interview awal adalah nilai rata-rata akuntansi, kemandirian, pengalaman kepemimpinan, nilai rata-rata IPK, kemampuan menulis, potensi untuk maju, kemampuan secara teknis dan reputasi universitas. Perekrut dari KAP, fakultas dan mahasiswa berpendapat bahwa nilai rata-rata akuntansi adalah faktor terpenting dalam proses rekrutmen. Moncada and Sanders (1999) memberi masukan kepada mahasiswa yang ingin bekerja di KAP setelah lulus sarjana harus memiliki perencanaan karirnya dengan membekali pengetahuan mengenai karakteristik karyawan yang diiginkan oleh perekrut KAP serta mengetahui penekanan karakteristik dalam tiap-tiap interview. Moncada and Sanders (1999) menyarankan kepada KAP untuk menekankan pada kebutuhan profesi untuk memotivasi mahasiswa dengan kemampuan komunikasi yang baik dan standar etika yang tinggi.

\section{Kerangka Berpikir}

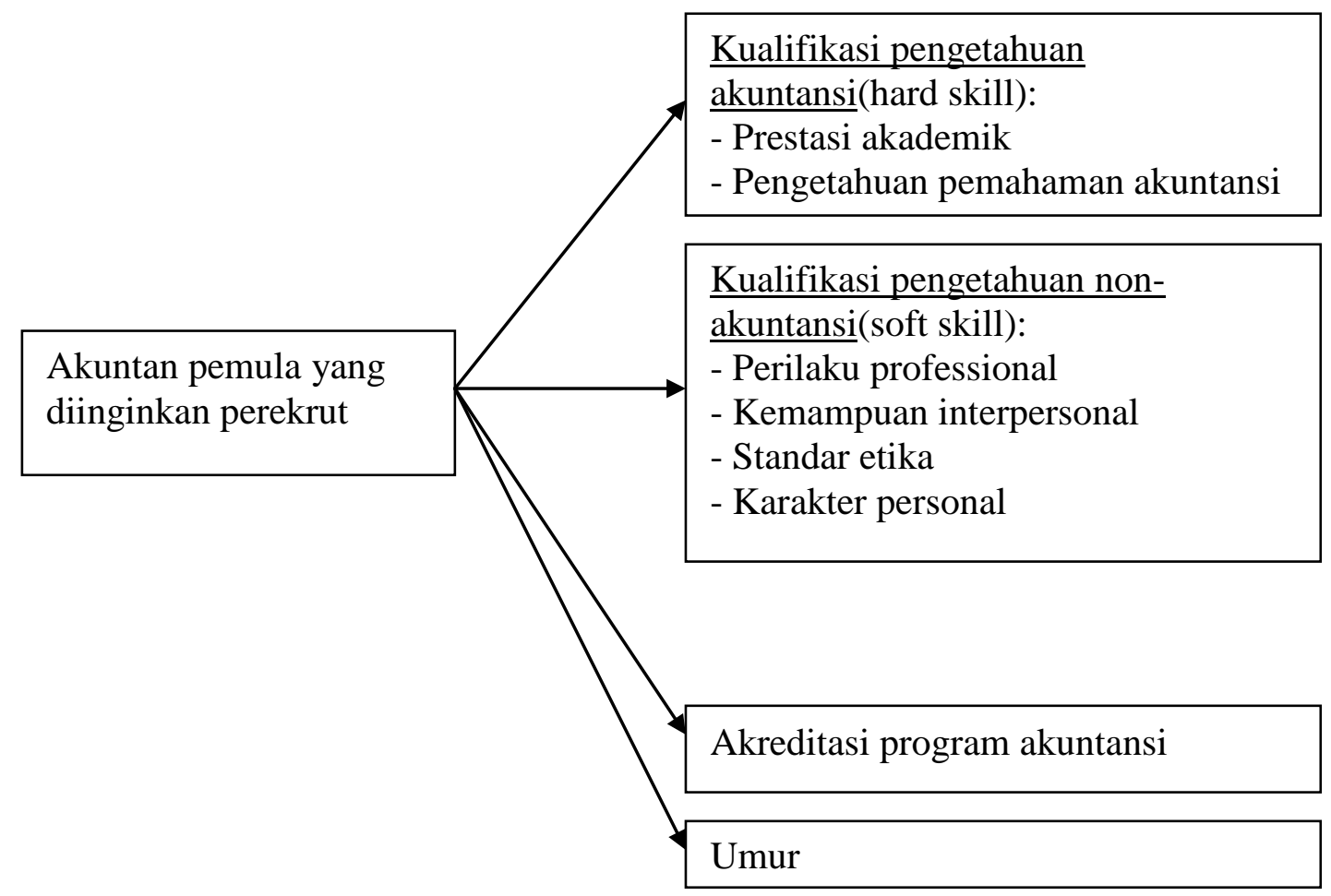

\section{METODOLOGI PENELITIAN \\ Metode Penelitian}

Penelitian ini termasuk dalam kategori penelitian kualitatif karena penelitian ini menekankan pengujian suatu teori melalui pengungkapan fakta atau kondisi realitas yang ada. Berdasarkan karakteristik masalah yang diteliti, metode penelitian yang dipergunakan oleh penulis dalam melakukan penelitian adalah bersifat studi deskriptif dengan jenis penelitian survei. Lingkungan (setting) studi dalam penelitian ini adalah studi lapangan (field study). Dan unit analisisnya kelompok yang dalam lingkungan organisasional KAP yaitu perekrut dari KAP. Horison waktu dari penelitian ini adalah studi satu tahap (one shot study) yaitu pengumpulan data yang lebih menekankan pada frekuensi tahap pengumpulan data yaitu satu tahap. Sedangkan skala pengukuran yang digunakan dalam penelitian ini adalah skala interval yang merupakan skala pengukuran yang menyatakan kategori, peringkat dan jarak construct yang diukur. Metode pengukuran kepentingan yang digunakan peneliti adalah skala Likert. 


\section{Metode Analisa Data}

Setelah melakukan pengumpulan data, maka data tersebut dianalisismenggunakan metode analisis faktor. Analisa faktor merupakan sebuah pendekatan statistik yang dapat digunakan untuk menganalisa hubungan antara sejumlah variabel dan menjelaskan variabel tersebut dalam bentuk umum berdasarkan faktor. Jadi, analisa faktor bertujuan untuk mengurangi data atau meringkas informasi yang terdapat dalam sejumlah variabel asli ke dalam seperangkat variabel yang jumlahnya lebih sedikit atau mengidentifikasi dimensi gabungan atau faktor dengan kehilangan informasi yang minimum. Setelah melakukan pengolahan data, maka data tersebut dianalisismenggunakan metode analisis faktor dengan rotasi varimax procedure. Metode varimax ini merupakan metode orthogonal yang berusaha meminimumkan (membuat sedikit mungkin) banyaknya variabel dengan muatan tinggi (high loading) pada satu faktor. Rotasi orthogonal menghasilkan faktor-faktor yang tidak berkorelasi satu sama lain (uncorrelated each other). Dan pada prinsipnya, analisis faktor digunakanuntuk mereduksi data, yaitu proses untuk meringkas sejumlah variabel menjadilebih sedikit dan menamakannya sebagai faktor. Dari faktor tersebut, akanmemunculkan tingkat varian yang menjelaskan seluruh makna yang terkandungdi dalam data yang ada.

\section{ANALISA PEMBAHASAN}

\section{Kategori soft skill yang paling diinginkan KAP selain pengetahuan akuntansi}

Pada penelitian ini, penulis menggunakan metode analisis faktor untuk mengidentifikasi karakteristik akuntan pemula yang dipertimbangkan KAP. Hal ini juga didasarkan pada penelitian yang dilakukan oleh Ahadiat and Smith (1994).Analisis faktor dalam penelitian ini bertujuan ingin menemukan suatu cara meringkas informasi yang ada dalam variabel awal menjadi satu set faktor baru, dan mengidentifikasi adanya struktur hubungan antarvariabel. Jenis analisa data yang digunakan dalam penelitian ini adalah Exploratory Analysis dengan metode analisa Principal Component Analysis dan metode rotasi Varimax Rotation, dengan bantuan software SPSS version 13.0. Principal component analysis bertujuan untuk mengetahui jumlah faktor minimal yang dapat diekstrak dan metode varimax ini merupakan metode orthogonal yang berusaha meminimumkan (membuat sedikit mungkin) banyaknya variabel dengan muatan tinggi (high loading) pada satu faktor. Dan untuk menentukan dapat atau tidaknya melakukan analisis faktor adalah melihat matriks korelasi secara keseluruhan dengan melakukan pengujian KMO MSA andBarlett test of sphericity, jika hasilnya signifikan atau diatas 0,50 berarti matriks korelasi memiliki korelasi signifikan dengan sejumlah variabel. Hasil analisa faktor akan menghasilkan nilai loading factor, yaitu hubungan antara masing-masing variabel dengan faktor yang dibentuk.Loading factor yang disarankanadalah diatas 0,50. Jika nilai loading faktor diatas 0,50 maka variabel tersebut dapat memenuhi kriteria untuk membentuk faktor. Dan hasil output SPSS dibawah ini menghasilkan KMO MSA sebesar 0,656 dan sudah memenuhi syarat yaitu diatas 0,5 begitu sehingga proses dapat dilanjutkan. Pada output bagian kelima sudah tidak terdapat variabel dengan loading faktor kurang dari 0,5 dan juga dengan Barlett test of sphericity juga signifikan pada 0,05 dan dapat disimpulkan bahwa analisis faktor dapat dilanjutkan dan variabel-variabel tersebut layak untuk dianalisis lebih lanjut.

Tabel

KMO and Bartlett's Test

\begin{tabular}{|l|r|}
\hline $\begin{array}{l}\text { Kaiser-Meyer-Olkin Measure of Sampling } \\
\text { Adequacy. }\end{array}$ & .656 \\
$\begin{array}{llr}\text { Bartlett's Test of } & \text { Approx. Chi-Square } & 2741.496 \\
\text { Sphericity } & \text { df } & 703\end{array}$ \\
\hline
\end{tabular}


Sig. .000

Berdasarkan hasil pengolahan data mengenai karakteristik akuntan pemula yang diinginkan oleh KAP dan diolah dengan analisis faktor diperoleh 9 faktor yang terbentuk dengan nilai Eigenvalues Rotation Sums of Squared Loadings sebesar 79,268\%. Nilai tersebut mencerminkan jumlah varians yang dihitung berdasarkan 9 faktor yang diterima. Artinya $79,268 \%$ dari total varians diperhitungkan sehingga menunjukan hubungan diantara variabel adalah tinggi dan kuat. Dari 54 item (pengukuran), 38 item mempunyai loading faktor diatas 0,50. Sedangkan sisanya mempunyai loading faktor kurang dari 0,50 atau loading faktor bertanda negatif. Loading faktor yang bertanda negatif mencerminkan arah yang berlawanan antar variabel dalam satu faktor yang terbentuk.

Berikut ini adalah tabel hasil analisa faktor :

Tabel Kategori karakteristik akuntan pemula berdasarkan analisis faktor

\begin{tabular}{|c|c|c|c|c|}
\hline Faktor & Karakteristik & Loading & Variance $(\%)$ & Kategori \\
\hline \multirow{10}{*}{ Faktor 1} & q37 & 0.830 & 15.563 & Kepribadian interpersonal \\
\hline & q36 & 0.801 & & \\
\hline & q38 & 0.793 & & \\
\hline & q33 & 0.763 & & \\
\hline & q39 & 0.753 & & \\
\hline & q34 & 0.725 & & \\
\hline & $\mathrm{q} 40$ & 0.699 & & \\
\hline & q32 & 0.665 & & \\
\hline & q22 & 0.563 & & \\
\hline & q35 & 0.531 & & \\
\hline \multirow[t]{6}{*}{ Faktor 2} & $\mathrm{q} 15$ & 0.894 & 12.665 & Perilaku profesional \\
\hline & q14 & 0.873 & & \\
\hline & $q 16$ & 0.815 & & \\
\hline & q30 & 0.723 & & \\
\hline & q28 & 0.692 & & \\
\hline & $q 12$ & 0.679 & & \\
\hline \multirow[t]{5}{*}{ Faktor 3} & $q 48$ & 0.918 & 12.400 & Gender \\
\hline & q46 & 0.912 & & \\
\hline & $\mathrm{q} 47$ & 0.911 & & \\
\hline & q49 & 0.906 & & \\
\hline & $\mathrm{q} 45$ & 0.856 & & \\
\hline \multirow[t]{5}{*}{ Faktor 4} & q52 & 0.866 & 9.490 & Lulusan perguruan tinggi \\
\hline & q51 & 0.860 & & \\
\hline & q50 & 0.842 & & \\
\hline & q44 & 0.575 & & \\
\hline & q53 & 0.528 & & \\
\hline \multirow[t]{3}{*}{ Faktor 5} & $q 17$ & 0.787 & 7.763 & Ketrampilan interpersonal \\
\hline & q19 & 0.781 & & \\
\hline & q18 & 0.656 & & \\
\hline \multirow[t]{3}{*}{ Faktor 6} & $q 13$ & 0.793 & 5.970 & Standar etika \\
\hline & q29 & 0.785 & & \\
\hline & $\mathrm{q} 43$ & 0.659 & & \\
\hline \multirow[t]{3}{*}{ Faktor 7} & q8 & 0.870 & 5.917 & Pengalaman kerja \\
\hline & q7 & 0.782 & & \\
\hline & $q 11$ & 0.526 & & \\
\hline Faktor 8 & $q 41$ & 0.758 & 5.659 & Keterlibatan dlm komunitas \\
\hline
\end{tabular}




\begin{tabular}{|l|c|c|c|l|} 
& $\mathrm{q} 42$ & 0.724 & & \\
\hline Faktor 9 & $\mathrm{q} 4$ & 0.644 & 3.842 & Pengetahuan akuntansi \\
\hline
\end{tabular}

Pada faktor pertama yang memiliki total nilai variance sebesar $15,563 \%$ meliputi 10 variabel dan masing-masing variabel loadingnya diatas 0,5 yang berarti hubungan diantara variabel adalah tinggi dan kuat. Item yang tercakup pada faktor pertama ini adalah Q37 (memiliki integritas), Q36 (jujur/dapat dipercaya), Q38 (memiliki rasa percaya diri), Q33 (berinisiatif), Q39 (tegas), Q34 (bertanggung jawab), Q40 (dapat diandalkan), Q32 (memiliki motivasi yang tinggi), Q22 (memiliki kemampuan untuk memecahkan masalah), Q35 (mampu mengatasi permasalahan pribadi).Pada faktor ini, penulis mengkategorikan sebagai kepribadian interpersonal.

Faktor kedua mencakup 6 variabel meliputi Q15 (mampu menyelesaikan jasa profesionalnya dengan kompetensi profesional), Q14 (mampu memelihara citra profesinya baik melalui perkataan maupun perbuatan), Q16 (melakukan pemberian jasa profesional dengan kecermatan dan keseksamaan profesional), Q30 (menjaga informasi yang berkaitan dengan klien dan perusahaan), Q28 (menghormati dan menjunjung tinggi kepercayaan publik, Q12 (patuh terhadap peraturan atau standar yang berlaku) yang memiliki total nilai variance sebesar 12,665 dan penulis mengkategorikan sebagai faktor perilaku profesional.

Faktor ketiga memiliki total variance 12,400 yang meliputi 5 variabel yaitu Q48 (Kandidat akuntan pemula wanita mendapatkan penerimaan yang sama dengan akuntan pemula pria dalam hal kesempatan promosi), Q46 (Kandidat akuntan pemula wanita mendapatkan penerimaan yang sama dengan akuntan pemula pria dalam hal perjanjian kerja), Q47 (Kandidat akuntan pemula wanita mendapatkan penerimaan yang sama dengan akuntan pemula pria dalam hal penawaran gaji), Q49 (Kandidat akuntan pemula wanita mendapatkan penerimaan yang sama dengan akuntan pemula pria dalam hal kualitas penugasan), Q45 (Kandidat akuntan pemula wanita mendapatkan penerimaan yang sama dengan akuntan pemula pria dalam hal rekrutmen kerja). Penulis mengkategorikan sebagai gender.

Pada faktor ke empat ini penulis mengkategorikan sebagai lulusan perguruan tinggi yang memiliki total variance sebesar 9,490 meliputi 5 variabel yaitu Q 52 (lulusan perguruan tinggi swasta terfavorit), Q 51 (lulusan dari perguruan tinggi negeri yang terbaik dan terfavorit), Q50 (lulusan dari universitas yang memiliki akreditasi A untuk program akuntansi), Q44 (mendapat referensi dari fakultas), dan Q53 (berumur antara 23-25).

Faktor ke lima total variance yang dimiliki sebesar 7,763 terdiri dari 3 variabel yang meliputi Q17 (memiliki kemampuan komputer yang memadai), Q19 (mampu beradaptasi), Q18 (kemampuan komunikasi secara lisan maupun tulisan). Pada faktor ini penulis kategorikan sebagai keterampilan interpersonal.

Faktor ke enam total variance yang dimiliki sebesar 5.970 terdiri dari 3 variabel Q13(mampu menolak penugasan yang tidak sesuai dengan pengetahuan dan keterampilan), Q29 (mengutamakan pertimbangan moral dan bukan aspek teknis), Q43 (mendapat referensi dari seseorang).

Faktor ke tujuh total variance yang dimiliki sebesar 5,917 terdiri dari 3 variabel yaitu Q8 (memiliki pengalaman kerja di non KAP), Q7 (memiliki pengalaman kerja di KAP), Q11 (lulusan magister akuntansi atau magister non akuntansi). Pada faktor ini penulis kategorikan sebagai pengalaman kerja.

Faktor ke delapan yang memiliki total variance sebesar 5,659 terdiri dari 3 variabel yaitu Q41 (aktif/terlibat dalam kegiatan ekstrakulikuler maupun kemahasiswaan), Q42 (aktif/terlibat dalam organisasi profesional). Pada faktor ini penulis kategorikan keterlibatan dalam komunitas.

Faktor ke sembilan yang memiliki total variance sebesar 3,842 yang terdiri dari 1 variabel yaitu Q4 (memiliki pengetahuan tentang Akuntansi, Audit, Perpajakan \& Akuntansi Manajemen). Pada faktor ini penulis kategorikan sebagai pengetahuan akuntansi 


\subsection{Kategori soft skill yang paling diinginkan KAP selain pengetahuan akuntansi}

Deskriptif Statistik ditinjau berdasarkan nilai rata-rata (mean) dan standar deviasi untuk masing-masing faktor. Kategori yang memiliki nilai mean tertinggi maka faktor tersebut menduduki peringkat pertama, artinya kategori tersebut dianggap paling penting oleh responden begitu juga sebaliknya jika kategori tersebut memiliki nilai mean terendah berarti kategori tersebut menduduki posisi peringkat paling bawah dan kategori tersebut dianggap oleh responden tidak penting. Adapun deskriptif statistik diurutkan berdasarkan tingkat kepentingan dari masing-masing faktor. Pengujian reliabilitas menggunakan metode Cronbach's Coefficient Alpha.Sebuah kategori dinyatakan reliable apabila Cronbach's Coefficient Alphalebih besar dari 0,70.

\section{Tabel .Deskriptif Statistik berdasarkan Tingkat Kepentingan}

\begin{tabular}{|c|c|c|c|c|c|c|}
\hline Peringkat & Faktor & Kategori & $\begin{array}{l}\text { Jmlh } \\
\text { Item }\end{array}$ & Mean & $\begin{array}{l}\text { Standard } \\
\text { Deviation }\end{array}$ & $\begin{array}{c}\text { Cofficient } \\
\text { alpha }\end{array}$ \\
\hline 1 & Faktor 2 & perilaku profesional & 6 & 4.5305 & 0.5280 & 0.9027 \\
\hline 2 & Faktor 9 & pengetahuan akuntansi & 1 & 4.3803 & 0.7044 & n.a \\
\hline 3 & Faktor 1 & $\begin{array}{l}\text { kepribadian } \\
\text { interpersonal }\end{array}$ & 10 & 4.3141 & 0.5105 & 0.9274 \\
\hline 4 & Faktor 5 & $\begin{array}{l}\text { ketrampilan } \\
\text { interpersonal }\end{array}$ & 3 & 4.1737 & 0.5630 & 0.8145 \\
\hline 5 & Faktor 3 & gender & 5 & 3.7972 & 0.9601 & 0.9642 \\
\hline 6 & Faktor 6 & standar etika & 3 & 3.2864 & 0.8073 & 0.7375 \\
\hline 7 & Faktor 4 & lulusan perguruan tinggi & 5 & 3.0563 & 0.7276 & 0.8547 \\
\hline 8 & Faktor 8 & $\begin{array}{l}\text { keterlibatan dlm } \\
\text { komunitas }\end{array}$ & 2 & 2.8310 & 0.6433 & 0.8172 \\
\hline 9 & Faktor 7 & pengalaman kerja & 3 & 2.7934 & 0.7525 & 0.7810 \\
\hline
\end{tabular}

Dari tabel deskriptif statistik diatas memberikan gambaran bahwa faktor 2 atau kategori perilaku profesional memiliki mean paling tinggi diantara 9 faktor lainnya yaitu sebesar 4,5305 dan standar deviasi 0,5280 artinya faktor tersebut merupakan kategori yang paling penting bagi responden dan berada di peringkat pertama. Ini membuktikan bahwa responden masih mengedepankan kategori perilaku profesional dibandingkan kategori lainnya.Rata-rata responden menganggap perilaku profesional para lulusan akuntansi merupakan kategori paling signifikan yang dipertimbangkan oleh KAP dalam penerimaan akuntan pemula.Hal ini memberikan pelajaran bagi para responden khususnya KAP agar kasus-kasus seperti Enron yang mencemari nama baik KAP tidak terjadi di Indonesia. Kekonsistensian responden dalam memilih faktor ini sebagai kategori perilaku professional sangat baik ditunjukkan dengan nilai cronbach alpha sebesar 0,9027. Hal ini sejalan dengan hasil penelitian Ahadiat and Smith (1994) yang menempatkan kategori perilaku profesional pada peringkat pertama dimana hal ini kontras dengan penelitian sebelumnya bahwa yang kategori yang paling penting adalah rata-rata IPK.

Berdasarkan nilai mean, peringkatkedua adalah faktor 9 atau kategori pengetahuan akuntansi dengan nilai mean 4,3803 dan standar deviasi 0,7044 artinya pengetahuan akuntansi merupakan kategori signifikan kedua yang dipertimbangkan oleh KAP. Pada kategori ini nilai cronbach alpha tidak dapat dinilai tingkat reabilitasnya karena hanya satu variable sedangkan dalam menilai reabilitas setidaknya paling sedikit ada dua variabel.Hasil dari pertanyaan terbuka sebagian besar responden menyatakan bahwa lulusan akuntansi saat ini belum cukup memenuhi kualifikasi yang diinginkan KAP seperti belum mendalami ilmu akuntansi, kurang mengikuti perkembangan teori dan standar akuntansi, kurangnya aplikasi dasar akuntansi, 
kurangnya pemahaman standar audit, kurang memperbarui atau mengupdating ilmu dengan ilmu yang terbaru, tidak menerapkan ilmu di lapangan, minimnya kemampuan untuk mengaitkan pengetahuan (misal: audit \& akuntansi) di bangku kuliah dengan praktek di lapangan, teori dan praktek audit yang belum memadai, kurang memahami prinsip dan konsep akuntansi, kurang menguasai proses akuntansi, belum mampu mengimplementasikan pelaksanaan audit, tidak menguasai proses audit khususnya audit laporan keuangan, lemah dalam analisis sistem informasi akuntansi, belum memahami bisnis perusahaan \& teknis sistem prosedur akuntansi sehingga terkadang kaku menghadapi dokumen akuntansi perusahaan, pemahaman dasar-dasar akuntansi masih banyak yang belum memadaipadahal hal-hal tersebut adalah hal pokok / dasar yang harus dimiliki oleh lulusan akuntansi, penguasaan di bidang akuntansi di lapangan / praktek kerja, minimnya praktek sehingga lulusan akuntansi masih kesulitan dalam penerapan teori akuntansi dengan penugasan. Pernyataan para responden tersebut haruslah membuka pikiran bagi kandidat akuntan pemula saat ini, ternyata masih banyak kualifikasi yang belum kita miliki sebagai seorang akuntan profesional.

Faktor 1 atau kategori faktor kepribadian interpersonal berada di peringkat ketiga yang memiliki nilai mean 4,3141 dan standar deviasi 0,5105 artinya karakter personal merupakan kategori signifikan ketiga yang dipertimbangkan KAP dalam penerimaan akuntan pemula setelah kategori perilaku profesional dan pengetahuan akuntansi. Pada kategori ini responden juga menampakkan konsistensi yang baik yang ditunjukkan pada nilai cronbach alpha sebesar 0,9274. Hal ini juga sejalan dengan hasil penelitian yang dilakukan oleh Novin and Pearson (1989) yang membuktikan kualifikasi pengetahuan non akuntansi juga memegang peranan penting dalam penerimaan akuntan pemula disamping pengetahuan teknis akuntansi. Lewis et.al (1983) dan Dinius and Rogow (1988) dalam Ahadiat and Smith (1994) juga menyatakan bahwa kepribadian interpersonal merupakan faktor yang penting setelah nilai IPK dan hasil interview. Hasil ini kontras denganHassel and Hennessey, Jr (1989) dalam Ahadiat and Smith (1994) dalam studinya mengindikasikan bahwa kategori yang paling penting adalah kepribadian yang berada di urutan pertama dan diikuti nilai IPK dan hasil interview. Dari hasil pertanyaan terbuka yang diajukan kepada responden menyatakan bahwa lulusan akuntansi saat ini belum cukup memenuhi kualifikasi sepertikurangnya kedewasaan dalam mengambil keputusan, menghadapi tekanan, minimnya akhlak dan komitmen,percaya diri, ketelitian, mandiri, adaptasi, teknologi serta masih belum dapat menyesuaikan dengan praktek di lapangan.

Urutan ke empat adalah faktor 5 atau kategori keterampilan interpersonal dengan nilai mean dan standar deviasi masing-masing sebesar 4,1737 dan 0,5630. Nilai cronbach alpha pada kategori ini sebesar 0,8145 yang menunjukkan responden cukup konsisten dengan kategori tersebut dan menganggap kategori keterampilan interpersonal juga merupakan kategori yang signifikan dalam keputusan penerimaan akuntan pemula. Hal ini juga sejalan dengan hasil penelitian yang dilakukan oleh Novin and Pearson (1989) yang membuktikan bahwa kualifikasi pengetahuan non akuntansi dalam hal ini ketrampilan yang dimiliki lulusan akuntansi berperan penting dalam kualifikasi penerimaan akuntan pemula disamping pengetahuan teknis akuntansinya.. Moncada and Sanders (1999) mengenai karakteristik akuntan pemula yang digunakan dalam memilih kandidat akuntan pemula dalam interview awal dan interview kedua dimana ketrampilan interpersonal menjadi kategori yang signifikan dalam interview kedua. Sedangkan penelitian yang dilakukan oleh Kirsch et.al (1993) yang menempatkan ketrampilan interpersonal pada kategori pertama yang paling penting menurut persepsi perekrut dari kantor akuntan publik. Ditambahkan pula oleh beberapa responden memberikan yang jawaban pada pertanyaan terbuka mengenai lulusan akuntansi yang belum memenuhi kualifikasi yang diinginkan KAP yaitu kurangnya kemampuan bahasa asing khususnya bahasa Inggris, penguasaan pemakaian komputer ketik 10 jari, kemampuan 
berkomunikasi lisan dan tulisan dalam bahasa asing, emosi dan membawa diri, kemampuan dalam hal sistem informasi dan tehnologi, komputer, dan akuntansi biaya, keterampilan yang terkait dengan akuntansi serta lemahnya ketrampilan analisis sifat transaksi.

Faktor 3 menempati urutan ke lima dengan nilai mean 3,7972 dan standar deviasi 0,9601 yaitu kategori perbedaan gender. Pada kategori gender, responden juga menganggap bahwa wanita juga berperan penting mendapat perlakuan yang sama dengan pria seperti dalam hal rekrutmen kerja, perjanjian kerja, penawaran gaji, kesempatan promosi serta kualitas penugasan. Pada kategori ini responden menunjukkan kekonsistensiannya dalam menjawab yang ditunjukkan dengan nilai cronbach alpha sebesar 0,9642. Artinya responden menganggap bahwa kategori ini juga penting sebagai faktor penentu keputusan penerimaan akuntan pemula.Hasil penelitian ini konsisten dengan studi yang dilakukan Graves and Powell (1995) yang menguji pengaruh persamaan jenis kelamin pada perekrut dan merupakan evaluasi pada kualifikasi pelamar yang membuktikan bahwa perekrut pria tidak ada perbedaan terhadap gender para kandidat pelamar dalam penerimaan kerja. Ditambahkan pula studi yang dilakukan Augustine(2004) yang menjelaskan bahwa tidak adanya perbedaan antara persepsi akuntan publik pria dan wanita terhadap isu kesempatan, perlakuan, penerimaan, komitmen serta akomodasi khusus.

Faktor 6 atau kategori standar etika yang memiliki nilai mean 3,2864 dan standar deviasi 0,8073 menempati peringkat enam. Nilai cronbach alpha pada kategori ini sebesar 0,7375 yang menunjukkan responden sangat konsisten dengan kategori tersebut dan menganggap kategori standar etika juga merupakan kategori yang signifikan dalam keputusan penerimaan akuntan pemula. Standar etika bagiAhadiat and Smith(1994)Moncada and Sanders (1999) juga faktor yang perlu ditekankan dalam penerimaan akuntan pemula karena dengan standar etika yang tinggi maka akan menghasilkan akuntan yang bermoralitas.Pada kenyataannya beberapa responden menganggap bahwa lulusan akuntansi saat ini belum cukup memenuhi kualifikasi yang diinginkan oleh KAP sebagai contoh moral dan etika bertindak (Code of Conduct)yang masih harus diasah, etika profesi/kode etik perlu di prioritaskan, SPAP kurang dikaitkan dengan keadaan di lapangan. Hal tersebut perlu menjadi wacana bagi para kandidat akuntan pemula untuk mengedepankan standar etika demi menjaga nama baik akuntan di mata masyarakat.

Peringkat ke tujuh adalah kategori lulusan sarjana perguruan tinggi atau faktor 4 dimana memiliki nilai mean 3,0563 dan standar deviasi 0,7276. Pada kategori ini responden juga menampakkan konsistensi yang cukup baik yang ditunjukkan pada nilai cronbach alpha sebesar 0,8547. Kategori inipun termasuk sebagai kualifikasi yang dipertimbangkan oleh KAP dimana KAP memendang bahwa lulusan yang berasal dari perguruan tinggi negeri dan swasta yang ternama dan memiliki akreditasi akuntansi yang baik maka cukup memberikan jaminan bagi KAP bahwa kandidat akuntan pemula tersebut layak untuk dipertimbangkan menjadi akuntan pemula di KAP.

Dan faktor 8 atau kategori keterlibatan dalam komunitas berada pada urutan peringkat ke delapan dimana memiliki nilai mean 2,8310 dan standar deviasi 0,6433 . Nilai cronbach alpha pada kategori ini sebesar 0,8172 yang menunjukkan reponden konsisten memilih kategori keterlibatan dalam komunitas sebagai faktor yang cukup signifikan dalam keputusan penerimaan akuntan pemula. Hasil temuan Ahadiat and Smith (1994), Moncada and Sanders (1999), juga memasukkan kategori keterlibatan dalam komunitas dalam kualifikasi yang layak untuk dipertimbangkan meskipun tidak terlalu signifikan. Dan bagi KAP keterlibatan akuntan pemula didalam komunitas cukup memberikan pelatihan bagi kandidat akuntan pemula dalam bekerja sama dalam tim kerja.

Peringkat sembilan adalah faktor 7 atau kategori pengalaman kerja, dimana pengalaman kerja juga merupakan kategori yang cukup signifikan dalam pertimbangan penerimaan akuntan pemula dengan ditandai dengan nilai mean 2,7934 dan standar deviasi 
0,7525. Responden juga konsisten memilih kategori ini sebagai salah satu kategori yang dipertimbangankan dalam keputusan menerima akuntan pemula yang ditandai dengan nilai cronbach alpha sebesar 0,7810. Hal ini sejalan dengan Ahadiat and Smith(1994),Moncada and Sanders (1999) yang juga mempertimbangkan pengalaman kerja sebagai kategori yang juga layak dipertimbangkan meskipun bukan yang utama. Beberapa responden menyatakan dalam partanyaan terbuka bahwa mereka menginginkan akuntan pemula yang memiliki pengalamanbekerja di KAP ataupun non KAP seperti pengalaman dalam membuat laporan, kertas kerja \& teknis kerja lainnya.

\section{DAFTAR PUSTAKA}

Abidin, Zubaidah Z., Penafort, Frances and Marzuki, Marzlin. 2005. Impadents to Women Accountants Career Profession in Malaysia.

Ahadiat, N. and K.J Smith,1994. A Factor analytic Investigation of Employee Selection Factors of Significance to Recruiters of Entry Level Accountant. Issues in Accounting education Vol.9 No.1.

Almer, Elizabeth D., Hopper, Jill R., and Kaplan, Steven E., 1998.The effect of DiversityRelated Attributes on Hiring, Advancement and Voluntary Turnover Judgment.Accounting Horizon, March.

Augustine S., Yvonne, 2004. Persepsi Akuntan Publik Pria dan Wanita Terhadap Isu yang Berkaitan dengan Akuntan Publik Wanita. Media Riset Akuntansi, Auditing dan Informasi, Vol.4 No.2 Agustus.

Baker, William M. and Harris, Albert L. 2001.Empirically Assessing Student Perceptions Of The Importance Of Student Characteristics.Journal of Information Systems Education.

Bundy, Paul and Norris, Daniel, 1992. What Accounting Students Consider Important in The Job Selection Process. Journal of Applied Business Research, Spring.

Cohen, Jeffery R., Pant, Laurie W. and Sharp, David J., 1998.The Effect of Gender and Academic Discipline Diversity on The Ehical Evaluations, Ethical Intentions and Ethical Orientation of Potential Public Accounting Recruits.Accounting Horizon, September.

Dahl, Shirley J. and Hooks, Karen L., 1985.Women Accountants, Today and Tomorrow. The CPA Journal, January.

DeNardo, Stephen and Thornton, John R, 1982.Recruiting : The New Horizon.Journal of Accountancy, October.

Gaffney, Mary A., McEwen, Ruth A., Welsh, Mary J., 1990. Advice to Firm : Gender Differences in Expectations of Succes Impact Recruiting. The CPA Journal, September.

Graves, Laura M. and Powell, Gary N., 1995.The Effect of Sex Similarity on Recruiters Evaluations of Actual Applicants : A Test of The Similarity-Attraction Paradigm.Personnel Psychology, 48.

Hansen, Randall S. and Hansen, Katharin. What Do Employers Really Want? Top Skills and Values Employers Seek from Job-Seekers. www.QuintCareer.com. Download tgl 13 September 2006.

Hardin, J.Russel, Reding, Kurt F., and Stocks, Morris H., 2002.The Effect of Gender On The Recruitment of Entry Level Accountants. Journal of Managerial Issues, Summer.

Hardin, J.Russel and Stocks, Morris H.,1995. The Effect of AACSB Accreditation on The Recruitment of Entry Level Accountants. Issues in Accounting Education, Spring.

Hayes, Robert D. and Hollman, Kenneth W., 1996.Managing Diversity : Accounting Firms and Female Employees. The CPA Journal, May.

Hartwell, Carolyn L., Lightle, Susan S. and Maxwell, Brian, 2005. High School Students' Perceptions of Accounting. The CPA Journal Online, January. 
Hunton, James E., Neidermayer, Presha E., Wier, Benson, 1996. Hierarchical and Gender Differences in Private Accounting Practice. Accounting Horizon, June.

Kirsch, Robert J., Leathers, Park E., and Snead, Ken C., 1993. Student versus recruiters perceptions of the importance of staff auditor performance variables. Accounting Horizon, December.

Lathan, M.H., Ostrowski, B.A., Pavlock, E.J., Scott, R.A., 1987. Recruiting Entry Level Staff : Gender Differences. The CPA Journal, January.

Moncada, Susan M. and Sanders, Joseph C., 1999.Do student and faculty know what characteristics recruiters are looking for? Perceptions in the Recruiting process. The CPA Journal, January.

Murtanto dan Gudono.1999.Identifikasi Karakteristik-karakteristik Keahlian Audit : Profesi Akuntan Publik di Indonesia. Jurnal Riset Akuntansi Indonesia, Januari.

National Association of College and Employers, 2006.The Top Qualities Employers Seek.Journal of Accountancy, January.

Nedrow, Cheryl, 2002. Employers Desire.Michigan State University, October.

Noe, Raymond A., Hollenbeck, John R., Gerhart, Barry, and Wright, Patrick M., 2006.Human Resources Mangement. Mc Graw Hill, fifth edition. International edition.

Novin, Adel.M and Pearson, Michael A.,1989. Non Accounting Knowledge Qualifications for Entry Level Public Accountants. Ohio CPA Journal, Winter.

Pabst, Donald F. and Talbott, John C., 1991.1990 Ohio Salary, Supply and Demand Study of Accounting Graduates. Ohio CPA Journal.Jan-Apr.

Pillsbury, Ceil M., Capozzoli, Liza and Ciampa, Amy, 1989. A Synthesis of Research Studies Regarding the Upward Mobility of Women in Public Accounting.Accounting Horizon.

Rankin, Larry J.1996. Evaluating Writing : A Selection Procedure for Recruiting Accountants. Ohio CPA Journal, February.

Rynes, Sara L., Orlitzky, Marc O. and Bretz, Robert D., 1997.Experienced Hiring Versus College Recruiting : Practices and Emerging Trends.Personnel Psychology, 50.

Sanders, Beatrice and Romeo, Leticia B., 2005.The Supply Of Accounting Graduates And the Demand For Public Accounting Recruits-2005; For Academic Year 2003-2004. American Institute of Certified Public Accountants, New York.

Scheuermann, Sandra B., Finch, J.Beth, Lecky, Marcella, Scheuermann, Larry, 1998. Why Women Leave Public Accounting. Business Forum.Winter.

Siegel, Gary, Kulesza,C.S., and Sorensen, James E.,1997. Surveying the present and future activities of corporate accountants.Are You Ready for The New Accounting?.Journal of Accountancy, August.

Trisnaningsih, Sri, 2004. Perbedaan Kinerja Auditor Dilihat dari Segi Gender. Jurnal Riset Akuntansi Indonesia, Januari.

Trapp, Michael W., Hermanson, Roger H., Turner, Deborah H., 1989. Current Perceptions of Issues Related to Women Empolyed in Public Accounting. Accounting Horizon, March.

Zuhroh, Diana, 2005. Mendesak, Kerjasama antara Jurusan Akuntansi dengan Praktisi.Media Akuntansi, ed.48, Tahun XII. 